\title{
Leading innovation: Empirical evidence for ambidextrous leadership from UK high-tech SMEs
}

Oluwafemi, Tolulope; Mitchelmore, Siwan; Nikolopoulos, Kostas

\section{Journal of Business Research}

DOI:

10.1016/j.jbusres.2019.10.035

Published: 01/10/2020

Peer reviewed version

Cyswllt i'r cyhoeddiad / Link to publication

Dyfyniad o'r fersiwn a gyhoeddwyd / Citation for published version (APA):

Oluwafemi, T., Mitchelmore, S., \& Nikolopoulos, K. (2020). Leading innovation: Empirical evidence for ambidextrous leadership from UK high-tech SMEs. Journal of Business Research, 119, 195-208. https://doi.org/10.1016/j.jbusres.2019.10.035

\footnotetext{
Hawliau Cyffredinol / General rights

Copyright and moral rights for the publications made accessible in the public portal are retained by the authors and/or other copyright owners and it is a condition of accessing publications that users recognise and abide by the legal requirements associated with these rights.

- Users may download and print one copy of any publication from the public portal for the purpose of private study or research.

- You may not further distribute the material or use it for any profit-making activity or commercial gain

- You may freely distribute the URL identifying the publication in the public portal ?
}

Take down policy

If you believe that this document breaches copyright please contact us providing details, and we will remove access to the work immediately and investigate your claim. 


\section{LEADING INNOVATION: EMPIRICAL EVIDENCE FOR AMBIDEXTROUS LEADERSHIP FROM UK HIGH-TECH SMES}

Tolulope Busola Oluwafemi ${ }^{1}$, Siwan Mitchelmore, and Konstantinos I.

Nikolopoulos*

Bangor Business School, Bangor University, Bangor, North Wales, United Kingdom

*Corresponding author at: Bangor University, Bangor Business School, College Road, Bangor, Gwynedd, LL57 2DG, UK.

Phone number: +44 1 248383796. E-mail address: kostas@bangor.ac.uk (Konstantinos I. Nikolopoulos).

'Declarations of interest: none'.

1 Present address at: School of Business and Economics, Thompson Rivers University, Canada 


\begin{abstract}
This study explores the important issue of how leadership facilitates employee innovation behaviors in SMEs. Ambidextrous leadership is introduced to the SME literature by investigating the influence of opening and closing leadership behaviors on employee's explorative and exploitative innovation behaviors. Using surveygenerated data from 98 high technology SMEs in the UK and by means of regression analyses, our findings reveal that opening and closing leadership behaviors predicted employee explorative and exploitative innovation behaviors respectively above all control variables. The combination of both leadership behaviors (ambidextrous leadership) also predicted employee ambidextrous innovation behaviors above all other leadership behaviors. A significant revelation was that the effect of ambidextrous leadership behaviors on employee ambidextrous innovation behaviors is mediated by adaptive/flexible leadership behavior. This study indicates that ambidextrous leadership is important for SMEs seeking to enhance employee innovative work behaviors.
\end{abstract}

Keywords: Ambidextrous leadership; Employee innovative behaviors; Adaptive/Flexible leadership 


\section{LEADING INNOVATION: EMPIRICAL EVIDENCE FOR AMBIDEXTROUS LEADERSHIP FROM UK HIGH-TECH SMES}

\section{Introduction}

In today's fast-paced, technology driven and ever-competitive business environment, innovation has become an essential strategy vital to firm performance, growth and survival (Bagheri, Mitchelmore, Bamiatzi and Nikolopoulos, 2018; Bodlaj, KadicMaglajlic and Vida, 2018; Lin, McDonough, Lin and Lin, 2013). Innovation, the creativity and implementation of new ideas, processes and products (West and Farr, 1990) is achieved through exploration and exploitation. Exploration innovation is often described as knowledge development through the exploration of new possibilities while exploitation innovation is value creation by focusing on exploitation of existing capabilities (Gupta, Smith and Shalley, 2006; He and Wong, 2004). Increasingly, it is believed that 'high performing' firms are those that are successful at ambidexterity - balancing and benefitting from both exploration innovation and exploitation innovation simultaneously (O'Reilly and Tushman, 2008; Shibata, Baba, Kodama and Suzuki, 2018).

Innovation, whether explorative or exploitative occurs as a result of stakeholder engagement (Leonidou, Christofi, Vrontis and Thrassou, 2018), particularly the behaviors of a major stakeholder group - employees (Ayuso, Rodríguez, GarcíaCastro and Ariño, 2011). This group of stakeholders play a pivotal role by discovering opportunities, generating innovative solutions beneficial to the organization financially, and maintaining competitive advantage (Venkataraman, 2002). Therefore, to generate ambidexterity, organizations must embrace a stakeholder engagement approach to foster employee's ambidextrous innovation behaviors - simultaneous explorative and exploitative innovation behaviors (Alghamdi, 2018). Explorative innovation behaviors is the increment of variance in employee behaviors through experimentation, autonomy and error learning, while exploitative innovation behaviors is associated with decreasing variance in employee behaviors through routine maintenance, refinement and standardization (Baškarada, Watson and Cromarty, 2016).

Considering the critical role of human agency within the organization (Birkinshaw, Hamel and Mol, 2008), several studies have examined the association between leadership and employee explorative and exploitative innovation behaviors (Alghamdi, 2008; Smith and Tushman, 2005; Vaccaro, Jansen, Van Den Bosch and Volberda, 2012). However, heterogeneous results have been observed in these studies, with results often ranging from positive to negative associations (Bledow, Frese and Mueller, 2011; Ryan and Tipu, 2013). Transformational and transactional leadership 
are the most investigated leadership styles in relation to explorative and exploitative innovation behaviors. Transformational leadership emphasizes the inspiration and motivation of followers while transactional leadership focuses on exchanges between leader and follower defined in terms of contingent reward and active management by exception (Bass, 1999). Although transformational leadership is mostly linked to fostering employee explorative innovation behaviors (Bagheri, 2017; Reuvers, van Engen, Vinkenburg and Wilson-Evered, 2008), scholars (such as Basu and Green, 1997; Jaussi and Dionne, 2003) found negative association between transformational leadership and employee explorative innovation behaviors. Furthermore, transformational leadership has consistently shown either non-significant or negative association to employee exploitative innovation behaviors (Vera and Crossan, 2004).

Organizational scholars have attributed these inconsistent findings to the inability of traditional leadership styles such as transformational and transactional leadership to capture dynamic innovation behaviors as these leadership behaviors were not developed specifically for innovative settings (Bledow et al., 2011; Rosing, Frese and Bausch, 2011). Moreover, due to their rigid nature, traditional leadership behaviors may be deficient in supporting the varying knowledge processes required to foster explorative and exploitative innovation behaviors (Bledow, Frese, Anderson, Erez, and Farr, 2009; Mumford and Licuanan, 2004). Thus, while these leadership behaviors may efficiently predict routine work, leadership of people in innovative settings may require the combination of complementary leadership approaches that correspond to the varying requirements of both explorative and exploitative employee innovation behaviors (Ancona, Goodman, Lawrence and Tushman, 2001; Gupta et al., 2006).

Based on the understanding that explorative and exploitative innovation behaviors are best conceived as having complementary effects on each other (Andriopoulos and Lewis, 2009), ambidextrous leadership theory has recently been proposed as a new approach to understand and manage the leadership of explorative and exploitative innovation behaviors. The theory suggests that leaders need to show two paradoxical leadership behaviors - opening and closing leadership - to foster employee explorative and exploitative innovation behaviors respectively. In addition, the flexible switching between opening leadership behaviors (OLB) and closing leadership behaviors (CLB) is expected to foster ambidextrous innovation behaviors in employees (Rosing et al., 2011).

In spite of these theoretical developments, there are scanty empirical studies on ambidextrous leadership theory (Alghamdi, 2018; Zacher, Robinson and Rosing, 2014; Zacher and Rosing 2015; Zacher and Wilden, 2014). Moreover, ambidexterity as a leadership theory is yet to be explored in the SME context as past research have placed 
more emphasis on the role of leadership in larger organizations (Bamiatzi, Jones, Mitchelmore and Nikolopoulos, 2015; Chang and Hughes, 2012; Lubatkin, Simsek, Ling and Veiga, 2006). Yet, the prescriptions from larger firms may be unsuitable for SMEs as it is well established that SMEs differ significantly from large firms as they tend to have limited human resources, limited financial resources, and limited managerial expertise (Cao, Gedajlovic and Zhang, 2009; Chang and Hughes, 2012). Considering these limitations, researchers have suggested reliance on leadership as a more influential factor in influencing innovative work behaviors in this sector compared to the larger sized organizations (Dunne, Aaron, McDowell, Urban and Geho, 2016; Vargas, 2015).

Understanding how to drive employee ambidextrous innovation behaviors is particularly crucial as a source of competitive advantage for SMEs as this sector often faces the challenge of adapting to environmental dynamism although unlike larger firms possessing restricted financial resources to do so (Chang and Hughes, 2012; Lubatkin et al., 2006). Hence, it is imperative for SMEs to focus on the stakeholder engagement activities of employees by fostering employee explorative and exploitative innovation behaviors, which can be positively influenced by leadership behaviors (Bagheri, 2017). By actioning this, SMEs can benefit from both exploration and exploitation innovation outputs regardless of financial limitations (Cao et al., 2009). Therefore, efficient management of the contributions of this stakeholder group to innovation can increase firm value greatly (Venkataraman, 2002).

Furthermore, the proposition of ambidextrous leadership does not clearly state how leaders are to operate the dynamics of switching between OLB and CLB. At best, Rosing et al. (2011) recommended that a necessary condition is flexibility of leadership behavior given that the need to demonstrate explorative and exploitative innovation behaviors occur extemporaneously and leaders will need to adapt their behaviors to these changing requirements. This suggests the need to demonstrate adaptive/flexible leadership behaviors, the modification of leadership style in response to unpredictable circumstances (Yukl and Mahsud, 2010). To the best of our knowledge, this research area is yet to be explored in relation to ambidextrous leadership.

To address these gaps in knowledge and to build on ambidextrous leadership theory, the present study adopts a stakeholder engagement approach by investigating ambidextrous leadership and its influence on employee innovation behaviors in the SME sector. In particular, we ask: (1) how much influence does ambidextrous leadership - opening and closing leadership behaviors - have on employee's explorative and exploitative innovation behaviors?; (2) how does the leader's adaptive/flexible leadership behaviors impact this association? 
This paper contributes to the discussion of SME leadership and innovation in two ways. Firstly, to the best of our knowledge we provide one of the first empirical evidence for ambidextrous leadership theory from SMEs. We demonstrate that OLB fosters employee explorative innovation behaviors and CLB fosters employee exploitative innovation behaviors. In doing so, we respond to calls to extend and validate research into leadership behaviors that predict innovation behaviors in SMEs (Kang, Solomon and Choi, 2015; Lin et al., 2013; Tung and Yu, 2016). Advancement in the SME leadership literature can have direct implications for SME viability and growth (Paradkar, Knight and Hansen, 2015). More so as the leadership role performed in SMEs is a critical issue in our understanding of competitive advantage and economic development (Bagheri, 2017).

Secondly, we build on ambidextrous leadership theory by elucidating the less understood area of how to switch between OLB and CLB by demonstrating a mediating effect of adaptive/flexible leadership behavior on the association between ambidextrous leadership and employee ambidextrous innovation behaviors. In doing this, we provide deeper insights into how to operationalize ambidextrous leadership and create a springboard for future research in their efforts to identify factors that aid operationalization of ambidextrous leadership. Overall, we provide comprehensive insights for SME leaders on how engage with their primary stakeholder-employees to enhance their innovation behaviors.

The rest of the paper is structured as follows: the literature on innovation and ambidextrous leadership are explored then hypotheses are proposed. Further, we present the methodology and discuss the findings. Finally, we highlight the theoretical and practical implications and provide suggestions for further research.

\section{Literature review}

\subsection{Duality of innovation and challenges of leading innovative pursuits}

Exploration and exploitation are distinct modes of innovation characterized by contradictory features and driven by different behaviors (Gupta et al., 2006; March, 1991). Although many models of innovation present exploration and exploitation innovation in a linear and sequential order, in reality, both occur extemporaneously therefore cannot be easily separated regardless of whether a firm is more inclined to exploration innovation or exploitation innovation (Anderson, De Dreu, and Nijstad, 2004; Berkhout and Van Der Duin, 2007). Excessive focus on exploration innovation may lead to the production of undeveloped technologies, while too much exploitation innovation may lead to reliability on old competencies at the expense of discovering better possibilities (Baškarada et al., 2016). Cao et al. (2009) demonstrated that a 
balance of exploration and exploitation innovation enhances firm performance by reducing the risks associated with over-emphasizing either exploration or exploitation innovation and as such missing the benefits of the other. Indeed, the combination of exploration and exploitation innovation have been found to be highly essential such that optimal innovation is reported by firms that are able to engage in both ( $\mathrm{O}^{\prime}$ Reilly and Tushman, 2008; Zacher and Rosing, 2015).

The stakeholder engagement approach of focusing attention on employee innovation behaviors through the influence of leadership is gaining popularity (Bagheri, 2017). Exploration innovation is driven by behaviors such as flexibility, experimentation, variance, taking risks and search. These behaviors help to generate novel products, new processes and competitive solutions. On the other hand, exploitation innovation builds on existing knowledge and skills to make incremental improvements through demonstration of behaviors such as refinement, choice, control, selection, efficiency, implementation and execution. (He and Wong, 2004; March, 1991; Levinthal and March, 1993). Engaging in behaviors that 'explore' new possibilities can lead to radical innovation; while engaging in behaviors that 'exploit' old certainties can lead to incremental innovation (Birkinshaw and Gupta, 2013; Bledow et al., 2009).

By fostering employee exploitative innovation behaviors, a firm ensures that there are sufficient resources available for exploration; likewise, the demonstration of exploration-type innovation behaviors can ensure that new processes and products are created that can be exploited in the long term (Rosing et al., 2011). Furthermore, poorly defined creative assignments may need exploitative innovation behaviors to provide structure and direction, while explorative innovation behaviors may also be required to drive the implementation of new/radical ideas (Bain, Mann and PirolaMerlo, 2001). By engaging too much in exploitative innovation behaviors, an organization stands at the risk of missing new knowledge; likewise, organizations that focus only on explorative innovation behaviors risk losing incremental benefits from old certainties (Mom, Van Den Bosch and Volberda, 2009). Put together, explorative and exploitative innovation behaviors are needed not only in specific phases of innovation but within the entire innovation process (Rosing, Rosenbusch and Frese, 2010). Hence, the undertakings referred to by a duality such as explorative and exploitative innovation behaviors need to be stimulated, balanced and integrated throughout an organization (Bledow et al., 2011).

Therefore, in pursuit of sustainable growth and innovation performance, leaders have been challenged to become ambidextrous by fostering sufficient levels of explorative and exploitative innovation behaviors in their followers (Andriopoulos and Lewis, 
2009; O'Reilly and Tushman, 2008). Nevertheless, the task of balancing both explorative and exploitative innovation behaviors is a challenging leadership endeavour as they are fundamentally different with each having varying requirements, thus necessitating divergent knowledge processes (March, 1991). Consequently, the innovation management process becomes complex and paradoxical, placing competing demands and tensions on the scarce resources of the firm (Gupta et al., 2006; March, 1991). Therefore, leaders in the context of innovation must strategically work to resolve multiple tensions continually as they work to achieve a balance between new and old activities; structured and chaotic activities; and uncertain and reliable activities to drive both explorative and exploitative innovation behaviors (Hunter, Thoroughgood, Myer and Ligon, 2011; Rosing et al., 2010).

These challenges are greater for SMEs where their low economies of scale and insufficient resources limit access to external networks and adequate human and financial resources needed to foster combined explorative and exploitative innovation behaviors (Kaufmann and Tödtling, 2002; Tidd and Bessant, 2011). Consequently, SME leaders must adopt appropriate strategies and develop new leadership competencies which effectively direct innovation behaviors and manage ambidexterity by aligning human capital to create maximum value for the business (Chen, Tang, Jin, Xie and Li, 2014; Tidd, Bessant and Pavitt, 2005). In today's innovation focused economy, much emphasis is given to employees, their creativity and ability to share new knowledge (Drucker, 2014; Florida and Goodnight, 2005). Stakeholder theorists have suggested that employees have a peculiar role and a relatively higher power among other stakeholders because they constitute the firm and in many cases they are the most important resource of the firm (Crane, Matten and Moon, 2004; Greenwood and Anderson, 2012). Indeed, the source of innovation is the creative and innovative behaviors of employees (Hotho and Champion, 2011). Therefore, engaging employees in innovation and examining employee's innovation behaviors is important as these behaviors indicate that an employee is functioning optimally (Seligman and Csikszentmihalyi, 2000).

Consistent with the concept of ambidexterity, employees are required to demonstrate adaptability by adjusting their behaviors between explorative and exploitative innovation behaviors accordingly (Alghamdi, 2018; Pulakos, Arad, Donovan and Plamondon, 2000). Typically, the cue for what type of innovation behavior to engage in, and when to switch between behaviors is received from the leader (Zacher et al., 2014). However, numerous leadership behaviors that have been examined in relation to employee innovation behaviors have yielded heterogeneous results (Chen, $\mathrm{Li}$, and Leung, 2016). A meta-analytical study of innovation leadership studies by Rosing et 
al. (2011) revealed a wide range of correlations between leadership behaviors and employee innovation behaviors, and the existence of mediating variables and moderating conditions in certain cases increased the observed inconsistent results. Therefore, organization scholars have suggested that the conventional leadership and management approaches used to foster employee innovation behaviors are inadequate as they are deficient in capturing the dynamic nature of innovation especially the requirement for ambidexterity (Drucker, 2014; Mumford and Licuanan, 2004).

\subsection{Ambidextrous Leadership Theory}

Following a meta-analytical study, which revealed that no particular leadership style was consistently related to employee innovation behaviors, Rosing et al. (2011) recommended that (i) leading innovation is a complex and paradoxical task, thus requiring corresponding leadership styles; (ii) ambidexterity is a central feature of innovation, which must be taken into account by innovation leadership theories. Summarily, the requirement for ambidexterity is what differentiates innovation performance from other forms of organizational performance.

Based on the understanding of the importance of ambidexterity to innovation leadership and to act on this understanding, Rosing et al. (2011) propose ambidextrous leadership theory, suggesting that to foster employee innovation behaviors, leaders need to show and flexibly switch between opening and closing leadership behaviors, aimed at increasing and decreasing variance in employee behaviors respectively. Rosing and colleagues argue that the best way to predict specific follower behavior(s) is to predict it by specific leader behavior(s). Opening leadership behaviors is hypothesized to encourage explorative innovation behaviors in employees by expanding their range of behaviors. OLB describes actions such as "allowing different ways of accomplishing a task, encouraging experimentation with different ideas, motivating to take risks, giving possibilities for independent thinking and acting, giving room for own ideas, allowing errors and encouraging error learning". Demonstrating these leadership behaviors increases variance in employee behaviors and helps to stimulate explorative innovation behaviors. By "opening" leadership behaviors, standard routines are broken down and new ways of thinking and doing things are encouraged.

OLB specifically matches the requirements faced by team and individuals to engage in exploration innovation and creative tasks.

Closing leadership behaviors (CLB) is hypothesized to encourage exploitation innovation behaviors in employees and decreasing variance in employee behaviors by demonstrating leadership behaviors such as "sanctioning errors, establishing 
routines, monitoring and controlling goal attainment, taking corrective action and paying attention to uniform task accomplishment". These leadership behaviors direct employee behaviors towards exploitation innovation. Switching flexibly between these OLB and CLB according to the changing demands of innovation and the environment marks out the ambidextrous leader and triggers employee ambidextrous innovation behaviors, the engagement in both explorative and exploitative innovation behaviors (Rosing et al., 2011; Rosing et al., 2010). The essential task of an ambidextrous leader is to decipher when and how to flexibly adjust OLB and CLB to the specific requirements of innovation at the appropriate time. Rosing et al. (2011) emphasized that mere demonstration of either OLB or CLB is insufficient to drive ambidextrous innovation behaviors.

The examples of opening and closing leadership behaviors are presented in Table 1.

Table 1. Examples of opening and closing leadership behaviors.

\section{Figure 1. Model of Ambidextrous leadership.}

As it is the case that there are no readily available systematic models that forecast the timing of exploration and exploitation innovation, operationalizing ambidexterity in practice is inconclusive, (see meta-analytic review by Junni, Sarala, Taras and Tarba, 2013) and, little knowledge exists on how to achieve the switch between OLB and CLB. Rosing et al. (2011) posit that flexibility and situational adaptability are the most important features of an ambidextrous leader. This suggestion underscores adaptive/flexible leadership behaviors (AFB) - the capability to adjust one's leadership approach to suit different or changing contextual demands in a way that facilitates performance (Kaiser and Overfield, 2010). It is pertinent to note that while ambidextrous leadership and AFB are both mindful and situationally aware leadership approaches, AFB is different from ambidextrous leadership in that ambidextrous leadership specifically relates to leadership of innovation efforts. Conversely, AFB is broader in scope and encompasses the leadership skill to approach emergencies or unpredictable work situations; solve problems creatively; handle work stress; engage in training and learning efforts; and demonstrate interpersonal adaptability (Charbonnier-Voirin and Roussel's, 2012; Yukl and Mahsud, 2010).

\section{Hypothesis Development}

\subsection{Employee Explorative Behaviors for Innovation}

By increasing variance in employee behaviors, a leader supports the adoption of generative and explorative thinking processes (Alghamdi, 2018). It is rarely the case that leaders have more information and knowledge on all aspects of the innovation 
task than their followers (Hunter et al., 2011). Typically, expertise is distributed across employees and employees often possess detailed knowledge and insights about the innovation processes and activities (Hoegl and Parboteeah, 2006). Therefore, such stakeholders require high autonomy as this will facilitate generation and implementation of new ideas (Shalley, Zhou and Oldham, 2004). Furthermore, leaders who exhibit OLB support error learning and allow employees to think independently and critically thereby creating a conducive culture that supports experimentation and creativity that challenge the status quo (Gumusluoglu and Ilsev, 2009; Zacher et al., 2014).

SME leaders are often considered as innovators who challenge the status quo and do things unconventionally (Schumpeter, 1965). Therefore, employees may take cues from the leader's own unconventional behaviors (Mintzberg, 1979) and be motivated to demonstrate explorative innovation behaviors. Furthermore, based on the possibility for increased environmental dynamism in high-tech SMEs, employees may be more receptive to a leader's style or behavior that increases variance (Vera and Crossan, 2004). Leaders showing OLB are likely to encourage employees to perceive the changing environment as a source of opportunity and help create a conducive environment necessary to support explorative innovation behaviors (Jansen, Vera and Crossan, 2009). Furthermore, OLB provides psychological safety, which would encourage employees engage in error learning and risk taking behaviors without fear of punishments in the event of failure (Edmondson, 1999).

Oldham and Cummings (1996) in their study of personal and contextual factors that foster employee innovation behaviors found that leadership behaviors that were perceived as controlling were negatively related to employees' explorative innovation behaviors. On the other hand, supportive supervision behaviors were reported to be positively related to employee explorative innovation behaviors. Other researchers (such as Alghamdi, 2018; Zacher et al., 2014) have found that OLB positively predicted employee explorative innovation behaviors beyond control variables.

Hypothesis 1: Opening leadership behaviors foster employee explorative innovation behaviors.

\subsection{Employee Exploitative Behaviors for Innovation}

Exploitation innovation focuses on improving existing knowledge through incremental improvement or refinement (He and Wong, 2004). To achieve this, a directive approach such as CLB is required to reduce variance in behaviors and ensure alignment of employee's behaviors to standard work routines (Bledow et al., 2011). Leaders who demonstrate CLB signal that employees should accomplish work in a routine but efficient manner and limit employee's efforts to pursue opportunities 
outside existing capabilities (Zacher et al., 2014). This facilitates exploitation innovation behaviors and fosters the improvement of existing knowledge (Alghamdi, 2008).

Although SMEs have been found to be more favourably disposed to exploration innovation rather than exploitation innovation (Zahra, Ireland and Hitt, 2000), there is evidence that SME leaders engage in behaviors that reduce variance in employee's behaviors. For example, Bamiatzi et al. (2015) demonstrated that SME leaders were autocratic in their leadership approach and in some cases showed high bureaucratic stance. In another study by Ardichvili, Cardozo and Gasparishvili (1998), SME leaders were reported to involve peers in decision-making but not subordinates. It is crucial for leaders in innovative settings to demonstrate CLB because these behaviors are necessary to transform creative ideas to commercial goods or services (Bledow et al., 2011). Additionally, Zacher et al. (2014) found that CLB positively predicted employee exploitative innovation behavior above and beyond their control variables.

Hypothesis 2: Closing leadership behaviors foster employee exploitative innovation behaviors.

\subsection{Employee Ambidextrous Innovation Behaviors}

OLB and CLB are complementary behaviors as each of them supplement the requirements that the other is unable to meet (Zacher and Wilden, 2014). Ambidextrous leadership suggests that although the leadership behaviors needed to foster employee explorative and exploitative innovation behaviors are different, they can be combined in an overall leadership approach that ensures an equilibrium of factors that support either part of the dualities of explorative and exploitative innovation behaviors (Bledow et al., 2011).

The synergistic effects of both OLB and CLB support employees to be ambidextrous which results in innovation performance above firms emphasizing either one of explorative or exploitative innovation behaviors (Alghamdi, 2018; Lewis, Andriopoulos and Smith, 2014; Lin and McDonough, 2011; Zacher and Wilden, 2014). For example, in a team where radical new product development is the goal; a leader may need to place more emphasis on OLB for motivation, intellectual stimulation and support of a conducive environment. While at another stage, a leader may need to take action to establish a common focus that integrates the best ideas while the other ideas are rejected so that the team can move forward (Rosing et al., 2010).

Focusing on employee behaviors to achieve ambidexterity is particularly crucial to SMEs because larger organizations may be able to afford structural ambidexterity where external units may be employed to take responsibility for either exploitation or 
exploration innovation, while in-house employees take responsibility for the other (Tushman and Reilly, 1996). On the other hand, due to limited human and financial capital, smaller organizations may have to settle for contextual ambidexterity or sequential ambidexterity. Contextual ambidexterity involves creating an organizational context where the same in-house employees are responsible for demonstrating both explorative and exploitative innovation behaviors by independently dividing their time between the two behaviors (Gibson and Birkinsahw, 2004). Sequential ambidexterity involves same in-house employees temporally switching between explorative and exploitative innovation behaviors based on a timed cycle (Duncan, 1976).

Although some researchers have suggested open innovation as an alternative approach for SMEs to achieve ambidexterity (Dahlander and Gann, 2010; Van de Vrande et al., 2009), limited research has been carried out on the sustainability of such pursuits. Furthermore, Xia and Roper (2016) reported that the success of such collaborations is still largely contingent on the internal resources of the firm especially the employees.

The combination of OLB and CLB has been found to predict employee ambidextrous innovation behaviors (Alghamdi, 2018; He and Wong, 2004; Zacher and Rosing, 2015). Furthermore, Bledow et al. (2011) demonstrated that alternating between complementary leadership behaviors to meet the duality of innovation creates a synergy that is a more functional and effective approach to support employee explorative and exploitative innovation behaviors simultaneously.

Hypothesis 3: Ambidextrous leadership (OLB * CLB) fosters employee ambidextrous innovation behaviors (Explorative * Exploitative innovation behaviors).

\subsection{The Effect of Adaptive/Flexible Leadership Behaviors on the Association between Ambidextrous Leadership and Employee Ambidextrous Innovation Behaviors}

Operationalizing ambidextrous leadership in practice is not well-understood (Junni et al., 2013). The proposition of ambidextrous leadership theory simply implies that leaders must exhibit flexibility of leadership behaviors to evaluate the environment and balance OLB and CLB to changing conditions of innovation (Junni et al., 2013). From the foregoing, it is plausible to make two assumptions. Firstly, leading ambidextrous innovation would require the demonstration of AFB from the leader so that the leadership approach adopted at any point in time is one that matches the current demands of innovation (Denison, Hooijiberg and Quinn, 1995). Secondly, AFB may elucidate necessary conditions such as the level of flexible leadership required 
for ambidextrous leadership behaviors to have highest impact on employee ambidextrous innovation behaviors (Bledow et al., 2011).

A leader may need to not only flexibly switch from one behavior to another, from task to task, but also from employee to employee (Bledow et al., 2011). Therefore, the aptitude for AFB could ease this process as optimal ambidexterity may be contingent on how well AFB is demonstrated by the leader to create an overall consistent leadership approach. We suggest that a leader's AFB is an essential factor that could influence the realization and effectiveness of ambidextrous leadership by helping in determining the most suitable leadership style for each changing situation (Larsson and Vinberg, 2010).

Leaders that exhibit AFB to new and emerging conditions of innovation signal to employees the need to ambidextrously manage innovation opportunities (Chang and Huges, 2012). The leader's ability to adapt to emerging conditions is the key to survival for SMEs (Bessant, Lamming, Noke and Phillips, 2005). More so, high-tech SMEs whose activities are fast-paced, highly creative, technology-driven and innovation focused (Damanpour, 1996).

Hypothesis 4: Adaptive and flexible leadership will influence the relationship between ambidextrous leadership and employee ambidextrous innovation behaviors.

From the discussion in the literature and the hypotheses formation, we present Figure. 2. as a framework to illustrate the expected associations among the variables.

\section{Figure 2. Relationship between Ambidextrous Leadership and Employee Ambidexterity.}

\section{Research Method}

This research was quantitatively undertaken using a hypothetico-deductive technique in which hypothesis are proposed and tested. The conceptual model that served as a basis for the empirical study is presented in Figure 2. We used existing multi-item scales for our survey and verified the responses through various analyses as described in the following section.

\subsection{Participants and Data Collection}

Data for this study were collected from 98 high-tech SME leaders from the United Kingdom. We focused on high-tech firms as these firms are most likely to be involved in higher volume of both exploration and exploitation innovation activities (Grinstein and Golman; 2006; Tajvidi and Karami, 2015). The sampling frame was sourced from 
Company House database and using purposive sampling we focused on eight hightech industries which have been identified by previous studies as engaging in high innovative activities in the UK (Wang and Rafiq, 2014; Hooker and Achur, 2014). Furthermore, we considered firm size by involving only firms with less than 250 employees (OECD and Eurostat, 2005).

Eight hundred and fifty (850) copies of the questionnaires were distributed primarily by post in three batches and telephone calls were made to prompt responses. Subsequent to the follow-up calls, 18 respondents preferred to complete the survey online. We sent the link to the survey to these 18 respondents using Survey Monkey. The survey respondents were individuals who held leadership positions in creative and innovative work teams in high-tech SMEs. Although, the CEO is considered to be most knowledgeable concerning issues such as innovation and firm performance (Baron and Hmieleski and Henry, 2012), communicating with CEOs can be difficult and could result to low response rate (Koryak et al., 2018). Therefore, the accompanying cover letter highlighted that the questionnaire was to be completed by any individual leader whose job involved actively leading and supporting creative and innovative work teams (e.g., R\&D units, production units).

The leaders were asked to give their responses based on the last three years considering employees they had worked with in these units. To avoid bias and common method variance, we adopted several strategies: we used brief, simple, specific and focused questions, ambiguous phrases were avoided and we checked each questionnaire for accurate completion.

Ninety-four (94) copies of the questionnaires were returned by post and 18 responses were received online, making a total of 112 responses to the survey from which 98 usable samples were obtained for analysis. This accounted for a response rate of $11.5 \%$, which is within the typical $10 \%-12 \%$ range for surveys of firm leaders (Hambrick, Geletkanycz and Fredrickson, 1993). No significant difference was observed from the online or postal responses. Fourteen questionnaires were rejected as incomplete, three from the online submission and 11 from the postal responses.

\subsection{Data Description}

The majority of our respondents were male $(\mathrm{N}=70 ; 71.4 \%)$ while the female respondents were $28(28.6 \%)$. With regards to age range of the respondents, $2(2 \%)$ were $17-25 ; 11(11.2 \%)$ were $26-35 ; 22(22.4 \%)$ were $36-45 ; 36(36.7 \%)$ were $46-54$ and $27(27.6 \%)$ were over 55 . Table 2 presents the demographics of the leader and their firms.

Table 2. Sample Description and Demographic characteristics. 
In terms of highest academic qualification 19 (19.4\%) had GCSE/vocational qualification; $51(52.0 \%)$ had at least a first degree and $28(28.6 \%)$ had obtained postgraduate degree. Majority of the firms in the sample $67(68.4 \%)$ have been established between 10-12years; 8 (8.2\%) have been established between 7-9 years; $10 \%(10.2 \%)$ have been established between 4-6 years and $13(13.3 \%)$ had been established within 0-3 years. The number of employees in the firms were 1-20 $(32.7 \%)$; 21-50 (15.3\%); 51-100 (13.3\%) and 101-250 (38.8\%).

\subsection{Sample}

The business sectors in our sample encompassed pharmaceutical and biotechnology (21), manufacturing (15), energy (10), information technology (8), engineering and machinery (22), software and computer services (8), telecommunication services (8) media, entertainment and games (6).

\subsection{Measures}

Our variables were measured using established multi-item scales. Scales were derived from extant studies and results from the pilot test with five business owners showed that meanings were clear with only a few adjustments made to improve the survey instrument.

\subsubsection{Opening and Closing Leadership Behaviors}

Opening and closing leadership behaviors were measured using two scales developed from the examples of opening and closing leadership behaviors provided by Rosing et al. (2011). The leaders rated themselves on a 5-point scale ranging from 1 (not at all) to 5 (frequently, if not always) according to how they engage in OLB and CLB. Cronbach's alpha for OLB scale was .80. Cronbach's alpha for CLB scale was .71. The items listed in Table 1 were used to measure OLB and CLB respectively. We modelled ambidextrous leadership as the multiplicative term of OLB and CLB, based on the argument that these two leadership behaviors are non-substitutable and complementary (Rosing et al., 2011). Other researchers have used this approach and have used the product term of opening and closing leadership behaviors to represent ambidextrous leadership (Zacher et al., 2014; Zacher and Wilden, 2014).

\subsubsection{Employee Explorative and Exploitative Innovation Behaviors}

Explorative and exploitative innovation behaviors were measured using scales developed by Mom et al. (2009). The leaders rated the extent to which their employees engaged in both explorative and exploitative innovation behaviors. Details of these items are provided in Table 4. Cronbach's alpha for explorative innovation behavior was .82 and .79 was recorded for exploitative innovation behavior. Following the approach of He and Wong, (2004); and Cao, Gedajlovic and Zhang (2009), we 
presented employee ambidextrous innovation behaviors as the multiplicative term of employee explorative and exploitative innovation behaviors because the combination of explorative and exploitative innovation behaviors is consistent with the concept of innovation ambidexterity (Wang and Rafiq, 2014; Zacher and Rosing, 2016). Although some other studies have modelled ambidexterity as the addition or absolute difference of exploration and exploitation values, a meta-analysis by Junni et al. (2013) revealed that using the product of exploration and exploitation was more strongly representative of ambidexterity as it implies that both exploration and exploitation constructs are independent but have a compensatory effect on each other.

\subsubsection{Adaptive/ Flexible Behavior}

The leader's adaptive/ flexible behaviors were measured using Charbonnier-Voirin and Roussel's (2012) 19-item scale containing 5 dimensions of adaptive behavior. The original scale consisting of 8 dimensions was developed by Pulakos et al (2000) and

has been reviewed and abridged by Charbonnier-Voirin and Roussel (2012). The leaders rated themselves on a 5-point scale ranging from 1 (not at all) to 5 (frequently, if not always). Details about these items are presented in Table 4. Cronbach's alpha for this scale was .81 .

\subsection{Demographic Variables and Control Variables}

The respondents reported their gender, age, education, leadership experience and firm age. We included leadership experience and firm age as control variables in our analysis because prior studies have suggested that these factors can be highly influential to the effectiveness and outcomes of the organization (Cavazotte, Moreno and Hickman, 2012; Wu, Levitas and Priem, 2005). Additionally, Wadhwa and Kotha (2006) demonstrated that firm age may be associated with a firm's rate of innovation.

\subsubsection{Transformational and Transactional Leadership}

We included transformational and transactional leadership behaviors as control variables based on the conceptual similarities between transformation leadership and opening leadership, as well as transactional leadership and closing leadership. We controlled for transformational and transactional leadership to examine if the proposition of ambidextrous leadership as a hypothetically precise innovation leadership behavior for innovative settings will be supported. Furthermore, transformational and transactional leadership have received substantial research attention in relation to explorative and exploitative innovation behaviors respectively (Rosing et al., 2011), and have been used as control variables in similar studies such as Zacher and Wilden (2014) and Zacher and Rosing (2015). 
Transformational and transactional leadership were measured using the Multifactor Leadership Questionnaire (MLQ Form 5X short; Avolio and Bass, 2004). The MLQ is one of the most frequently used instruments in the leadership literature and is considered to be highly reliable and well validated. Items in the MLQ were answered on 5-point scale ranging from 1 (not at all) to 5 (frequently, if not always). MLQ is based on seven factors, measuring transformational versus transactional leadership attributes, namely Idealized Influence, Inspirational Motivation, Intellectual Stimulation, Individualized Consideration, Contingent Reward, Management-byexception, and Laissez-faire. Cronbach's alpha for transformational leadership was .82 , and transactional leadership .84 .

\subsection{Common-Method Bias}

Because the use of a single survey for data collection creates the potential for common method bias, we took procedural steps to reduce the risk of bias. Following the recommendation of (Podsakoff, MacKenzie, Lee, and Podsakoff, 2003), we randomized the order of the survey items, eliminated ambiguity, and emphasized to respondents their confidentiality protection and pointing out that there were no right or wrong answers. In addition, we conducted a Harman One-factor test (Podsakoff et al. (2003). No single factor was dominant. The highest variance explained by a single factor was $19.9 \%$. Therefore, common method variance was not found to hold a serious threat to our findings.

\section{Data Analysis and Results}

We used linear regression procedure on IBM SPSS AMOS software version 22 to analyse the collected data and test the hypothesized relationships in $\mathrm{H} 1, \mathrm{H} 2$ and $\mathrm{H} 3$. Hypothesis 4 was tested using the Hayes' (2013) PROCESS macro package for SPSS.

\subsection{Measurement Validation}

Before testing the hypotheses, we examined the test validity and reliability of our measurement. First, we examined sampling adequacy for factor analysis by applying Bartlett's sphericity test and Kaiser-Meyer- Olkin (KMO) test. The Bartlett's Test of sphericity is significant $(0.000<0.05)$; approx. Chi-square 2034.839; $\mathrm{df}=666$. The KMO value obtained is acceptable $0.66>0.5$. Kaiser (1974) recommend 0.50 (value for KMO) as minimum. Our results indicate that responses given with the sample are adequate and factors are well correlated for analysis (Cerny and Kaiser, 1977).

Using the criterion of Fornell and Larcker (1981), we examined convergence validity through average variance extracted (AVE) and composite reliability (CR). AVE measures the level of variance captured by a construct versus the level due to measurement error. AVE should be equal to or greater than 0.5 and composite reliability is satisfactory when the value is above 0.7 . Table 4 shows the results with 
satisfactory values for AVE and CR except for adaptive/flexible leadership which had AVE value of 0.43 . However, Fornell and Larcker (1981) suggested that a value of 0.4 can be accepted if the values of the composite reliability is in the acceptable range.

All cronbach's alphas exceeded 0.70 (Cronbach, 1951, Nunnally, 1978) to confirm individual item reliability and internal consistency. We validated the scales using factor analysis, in which as shown in table 4, the values for the factor loadings are about the threshold of 0.5 or higher (Bagheri et al., 2018), indicating the significant level of the factor loadings and explicitness of factor composition. Furthermore, the factor analysis showed that the items had their highest factor loadings on their theoretically relevant factor. The average variance extracted for each construct exceeded the squared correlation with the other constructs. This indicates discriminant validity (Fornell and Larcker, 1981). All values surpassed the threshold to justify validity and reliability.

\section{Table 3. Means (M), Standard Deviations (SD), and Correlations of Variables.}

\section{Table 4. Reliability and Validity.}

Confirmatory factor analyses (CFA) were conducted to check the distinctiveness of the measures. We assumed that an adequate fit of the factor models exists when we obtain a comparative fit index (CFI) of .90 or higher and a root-mean-square error of approximation (RMSEA) of .08 or lower (Zacher et al., 2014). The results of the CFA (Table 5) also demonstrate that the scales have construct validity.

\section{Table 5. CFA for goodness-of fit measurement}

We assessed multicollinearity by examining tolerance and variance inflation factor (VIF). Multicollinearity was not an important issue for our results as variables were centered and the variance inflation factor (VIF) recorded in any of the models did not exceed 10, and the tolerance values were all above 0.2 which are accepted as the threshold for regression models (Hair, Anderson, Tatham and Black, 1995; Kutner, Nachtsheim, and Neter, 2004). Table 6 shows the values for the VIF scores and tolerance levels.

\section{Table 6. VIF scores and Tolerance levels.}

\subsection{Test of Hypotheses}

We tested hypotheses 1, 2 and 3 using hierarchical regression model. The control variables: firm age, leadership experience, transformational and transactional leadership were entered in the first step followed by the independent variables. To test hypothesis 3, we applied a moderation analysis by creating interaction terms of OLB and CLB to represent ambidextrous leadership and interaction terms of 
exploitative and explorative innovation behaviors to represent employee ambidextrous innovation behaviors. The empirical strategy follows Fig 2.

Hypothesis 1 was supported with a positive and significant relationship between OLB and employee explorative innovation behaviors $(\beta=.31, \mathrm{p}<.000)$. CLB did not predict employee explorative innovation behaviors $(\beta=.10, \mathrm{p}=.274)$.

As hypothesized, CLB was the only significant predictor of employee exploitative innovation behaviors $(\beta=.28, p=.006)$. This confirms hypothesis 2 . OLB did not predict employee exploitative innovation behaviors $(\beta=.09, \mathrm{p}=.311)$.

In confirmation of hypothesis 3 , we found a positive and significant association between ambidextrous leadership and employee ambidextrous innovation behaviors $(\beta=.32, p=.016)$. Figure 3 shows the effects of ambidextrous leadership on employee ambidextrous innovation behaviors.

Hypotheses 1, 2 and 3 were all supported. When the predictor variables are added in the regression, holding other variables constant, the explanatory power of the models are significantly increased. The regression results are presented in Table 6 .

To test hypothesis 4, we explored the likelihood of a mediating effect by examining the direct indirect associations of AFB through the bootstrap estimation approach with 5000 samples (Shrout and Bolger, 2002). This technique provides robust estimation of sampling variances and confidence intervals (Efron, 1979). We found a significant indirect effect of ambidextrous leadership on employee ambidextrous innovation behaviors through adaptive/flexible leadership, $\beta=0.262,95 \%$ level of confidence, confidence interval $[0.0809,0.5458]$. The completely standardized indirect effect coefficient is $\beta=0.113$, confidence interval [0.032, 0.233]. In addition, we found that in the presence of adaptive/flexible leadership, the direct effect of ambidextrous leadership on employee ambidextrous innovation behaviors reduced in significance, consistent with partial mediation (See Figure 4). Following the recommendation of Wen and Fan (2015), we report the effect size of this partial mediation using the traditional mediation effect size measure of ratio of indirect effect to total effect of $X$ on $Y(\beta=.2365,95 \%, C I .0700, .5121)$ This appears to be a large effect.

Figure 3. The effect ambidextrous leadership on employee ambidextrous innovation behaviors.

Figure 4. The mediating effect of Adaptive/flexible leadership.

Table 7. Results of Regression Analyses. 


\section{Discussion and Implications}

\subsection{Discussion}

In this study, we take a primary stakeholder engagement approach by examining the impact of ambidextrous leadership on employee innovation behaviors. First, our results provide support that OLB is effective to foster explorative innovation behaviors and CLB is effective to support exploitative innovation behaviors in SMEs. Our findings suggest that leaders who engage in OLB and CLB influence follower's behaviors in ways that are consistent with the leaders' behavior. Indeed, OLB could create a conducive environment where creativity and learning thrives (Alghamdi, 2018; Edmondson, 1999). On the other hand, by directing followers to focus on goal accomplishments using CLB, exploitation innovation behaviors are encouraged (Zacher et al., 2014).

Zacher et al. (2014), Rosing et al., (2010), and Zacher and Wilden (2004) have reported similar patterns of results. However, these studies were based in the context of large organizations. Although there are contentions that leadership and management practices to support innovation behaviors are much likely to be the same in all contexts and organizational sizes (Amabile, Conti, Coon, Lazenby and Herron, 1996; Bommer and Jalajas, 2002); it is erroneous to conceive SMEs as mini versions of large firms. It has been well documented that SMEs differ from larger firms in several ways such as decision-making processes and operating environment (Hotho and Champion, 2011; Shrader, Mulford and Blackburn, 1989) which justifies the need for SME sector specific innovation leadership research. Hence, our resolve to undertake this study using a representative dataset collected from the SME sector. Our findings are particularly reliable for the SME context as our data were collected from SME firms that are likely to encounter similar challenges in their management of tensions and trade-offs related to fostering exploration and exploitation innovation behaviors (Andriopoulos and Lewis, 2009).

Our results also demonstrate that OLB and CLB function interdependently to foster employee ambidextrous innovation behaviors (He and Wong, 2004; Rosing et al., 2011). As discrete leadership behaviors, OLB and CLB are insufficient to support employee ambidextrous innovation behaviors. As shown in Figure 3, employee ambidextrous behaviors was highest when both OLB and CLB were high. Indeed, prior research have argued that conventional leadership and management approaches are inadequate to foster ambidextrous innovation behaviors. These studies have suggested the need for a combination of leadership behaviors to match the complexity and pace of innovation (Ancona et al., 2001; Bledow et al., 2009). Our results provide insights about the specific leadership behaviors that SME leaders need to show to foster employee innovation behaviors that can generate single and multiple types of 
innovation notwithstanding limited resources (Kaufmann and Tödtling, 2002) and innovation paradoxes (Hunter et al., 2011). We extend research on ambidextrous leadership by showing that the combination of high OLB and CLB yields the highest level of employee ambidextrous innovation behaviors.

In our study, we sought to go beyond simply identifying the effect of OLB and CLB on employee innovation behaviors by investigating how adaptive/flexible leadership behavior of the leader may affect the impact of ambidextrous leadership behaviors on employee ambidextrous innovation behaviors. More so as previous studies which identified mediators between leadership and employee innovation behaviors have focused mainly on characteristics of the employee such as creative self-efficacy (Gong, Huang and Farh, 2009), identification with the leader (Wang and Rode, 2010) and creative identity (Wang and Zhu, 2011). Our study reveals that AFB is a mediator between ambidextrous leadership and employee ambidextrous innovation behaviors. Thus, AFB is a potential pathway through which ambidextrous leadership is operationalized. Based on the dimension of AFB to solve problems creatively and manage work stress effectively, those leaders who are high on AFB may be able to manage the tensions and paradoxes of innovation better. Additionally, because of their flexibility, leaders may be able to relate with different types of employees and switch their leadership behaviors according to the needs of different employees.

Consonant with Rosing et al. (2010), our result shows that behavioral integration and flexibility of leaders is crucial to fostering employee ambidextrous innovation behaviors. Our result further demonstrates that it is a combination of different leadership behaviors, which drive ambidextrous innovation behaviors. Thus, our study supports Rosing et al. (2011) that leading innovation is a complex process and leaders need to be flexible and engage in complex, wide-ranging and sometimes opposing behaviors to facilitate employee innovation behaviors (Rosing et al., 2011). If these leadership behaviors are well integrated, they could form a strong leadership competency to support employee ambidextrous innovation behaviors (Rosing et al., 2010; Rosing et al., 2011).

Given that ambidextrous leadership has been positioned as a hypothetically precise approach to leading innovation behaviors, it was important to test the core proposition of the theory while controlling for other leadership behaviors such as transformational and transactional leadership. It was interesting to find that ambidextrous leadership predicted employee innovation behaviors above and beyond transformational and transactional leadership behaviors. Zacher et al. (2014) had also reported this same pattern. Therefore, our findings validate ambidextrous leadership theory for leadership of innovation. 


\subsection{Theoretical Implications}

This study breaks new ground in SME research by providing initial evidence for ambidextrous leadership in the sector and suggests how to maximise leadership behaviors to support employee's innovation behaviors. The study of entrepreneurs as leaders is an area where we have little knowledge both in the leadership and entrepreneurship literatures (Bamiatizi, et. al, 2015). Little agreement exists on how leadership can be developed and how theories on leadership can be transferred into practice (Bagheri, 2017, Iles and Preece, 2006). From those few studies that have considered leadership in the SME literature, they conclude that the impact of leaders and leadership is a crucial factor in the success or failure of SMEs (Lin et al., 2013; Matzler, Schwarz, Deutinger and Harms, 2008). We reason that it is important to study ambidextrous leadership in the context of SMEs as a means to foster employee innovation behaviors to drive maximum innovation performance in the sector despite having limited resources. More so, as SME leaders acknowledged that they are constantly in search of ways to drive employee innovation behaviors so that they can compete effectively with the large firms (CIPD, 2012).

This study provides empirical evidence for ambidextrous leadership theory and assists evolving theories on innovation and leadership in the SME sector. Our study demonstrates that leading innovation is a dynamic task and that a complex relationship exists between leadership behaviors and employee innovation behaviors. Further, our findings suggest that the operationalization of ambidexterity needs clearer understanding at a theoretical and methodological level. For example, more knowledge is needed to understand the mechanisms required for switching between OLB and CLB. We revealed that AFB is a relevant factor mediating between ambidextrous leadership and employee ambidextrous innovation behaviors. Therefore, we extend ambidextrous leadership theory by suggesting AFB as one method to examine the temporal dynamics of integrating OLB and CLB. Finally, we suggest the need for more understanding of ambidexterity at the individual level to advance research on how leaders and employees manage the tensions and paradoxes required to be ambidextrous.

\subsection{Practical Implications}

Our findings contribute directly to practice by demonstrating that SME leaders can improve the growth and competitiveness of their business by demonstrating OLB, CLB and the combination of both leadership behaviors to foster employee innovation behaviors. Understanding the concept of ambidexterity and its role in driving innovation as well as the roles required of leaders and employees will benefit these stakeholder groups and the organization. Therefore, a key practical implication is the need to educate leaders and employees about the duality of innovation and the need 
to flexibly switch between behaviors. For example, understanding that higher levels of OLB fosters higher levels of employee explorative innovation behavior and that CLB is essential to driving employee exploitative innovation behaviors. Additionally, understanding that integrating OLB and CLB into a leadership approach has the greater potential to drive ambidextrous innovation behaviors of employees (Barney and Wright, 1998; Jansen, et al., 2009). Over time, this is likely to generate improved innovation leadership system and overall organizational success (Zacher et al., 2014).

SME leaders can use our findings to promote employee awareness concerning the complexities of the innovation process and sensitize them about the roles of OLB, CLB and AFB in fostering innovation behaviors. Furthermore, it is important to educate employees on the requirement for them to be equally ambidextrous. This awareness can help employees to be receptive of ambidextrous leadership behaviors demonstrated by the leader. It could also stimulate the stakeholders to seek ways to help themselves engage and balance explorative and exploitative innovation behaviors.

In addition, the findings of this paper may have important implications for leadership selection, training and development in SME context. Educators in this sector can apply our findings to their approach in training of SME leaders to understand the significance of ambidextrous leadership in fostering innovation with a view to assist them develop well-integrated leadership behaviors to enhance their effectiveness in supporting employee innovation behaviors.

\subsection{Limitations and Directions for Future Research}

Despite the valuable new insights offered by our study, it comes with certain limitations, which need to be considered for future research. Firstly, our findings are country and context specific. The UK context is an important one as SMEs are significant contributors to the health and wealth of the economy; nevertheless, focusing on one country can limit the generalizability of results. Future studies of SMEs in other countries would be of value, which could help evaluate the generalizability of the current findings. For further validation of ambidextrous leadership theory, future studies could also examine business sectors other than hightech industries to assess whether the findings of this study are consistent across different contexts.

Secondly, data was collected only from the SME leader's perspective. This may lead to common method bias and self-report bias (Podsakoff et al., 2003) as leaders may not report their leadership behaviors or the employee behaviors accurately. However, we took several steps to alleviate threats of common method bias as reported in the data analysis section and our results of Harman's one factor test suggests that common 
method variance is not a serious concern. We recommend that future studies should include peers and employees as research participants to improve the chances of generating unbiased ratings.

Thirdly, a larger sample and other data collection methods could offer further validation of our findings. We suggest that experimental research, qualitative data collection methods, diary study and longitudinal study may be helpful to provide unbiased and invaluable insight into the dynamics of leadership ambidexterity and may reveal non-linear associations as well as significant causal evidences.

Also, some important variables could not be controlled for within the scope of this study such as organizational culture and employee job characteristics. We suggest that future studies should examine these variables as well as the individual, firm and contextual factors and/ or barriers that may influence employee innovation behaviors. For example, it would be beneficial to know how the job characteristics of the employees and self-efficacy influence their innovation behaviors and performance because businesses differ in the extent to which employees are required to engage in explorative and exploitative innovation behaviors (Shalley, Gilson and Blum, 2009).

In addition, studies are needed to identify the antecedent behaviors and competencies such as personality traits and emotional intelligence that may help to explain subtle characteristics required to be ambidextrous. This may help to further reveal how best to operationalize ambidextrous leadership.

\subsection{Conclusion}

This study recognises the importance of the interaction between SME leaders and one of its primary stakeholders, its employees. We contribute to current understanding on how leadership facilitates employee innovation behaviors in SMEs by providing support for ambidextrous leadership in SMEs and we have discussed how SME leaders can use this proficiency to drive employee innovation behaviors. Furthermore, as our study has shown, this strengthened stakeholder influence and relationship can yield value by achieving a source of competitive advantage through employee ambidextrous innovation behaviors. 


\section{References}

Alghamdi, F. (2018). Ambidextrous leadership, ambidextrous employee, and the interaction between ambidextrous leadership and employee innovative performance. Journal of Innovation and Entrepreneurship, 7(1), 1.

Ancona, D.G., Goodman, P.S., Lawrence, B.S. \& Tushman, M.L. (2001). Time: A new research lens. Academy of management Review, 26(4), 645-663.

Anderson, N., De Dreu, C.K. \& Nijstad, B.A. (2004). The routinization of innovation research: A constructively critical review of the state-of-the-science. Journal of organizational Behavior, 25(2), 147-173.

Andriopoulos, C., \& Lewis, M. W. (2009). Exploitation-exploration tensions and organizational ambidexterity: Managing paradoxes of innovation. Organization science, 20(4), 696-717.

Amabile, T.M., Conti, R., Coon, H., Lazenby, J. \& Herron, M. (1996), “Assessing the work environment for creativity", Academy of Management Journal, Vol. 39 No. 5, pp. 1154-84.

Ardichvili, A., Cardozo, R. N \& Gasparishvili, A. (1998). “Leadership Styles and Management Practices of Russian Entrepreneurs: Implications for Transferability of Western Hard Interventions," Human Resource Development Quarterly 9(2), 145-155.

Avolio, B. J., \& Bass, B. M. (2004). MLQ - multifactor leadership questionnaire. Menlo Park, CA: Mind Garden.

Ayuso, S., Ángel Rodríguez, M., García-Castro, R., \& Ángel Ariño, M. (2011). Does stakeholder engagement promote sustainable innovation orientation?. Industrial Management \& Data Systems, 111(9), 1399-1417.

Bagheri, A. (2017). The impact of entrepreneurial leadership on innovation work behavior and opportunity recognition in high-technology SMEs. The Journal of High Technology Management Research, 28(2), 159-166.

Bagheri, M., Mitchelmore, S., Bamiatzi, V., \& Nikolopoulos, K. (2018). Internationalization Orientation in SMEs: The Mediating Role of Technological Innovation. Journal of International Management.

Bain, P.G., Mann, L. \& Pirola-Merlo, A. (2001). The Innovation Imperative. The Relationships between Team Climate, Innovation, and Performance in Research and Development Teams. Small Group Research, 32(1), 55-73.

Bamiatzi, V., Jones, S., Mitchelmore, S., \& Nikolopoulos, K. (2015). The role of competencies in shaping the leadership style of female entrepreneurs: The case of North West of England, Yorkshire, and North Wales. Journal of Small Business Management, 53(3), 627-644.

Barney, J. B., \& Wright, P. M. (1998). On becoming a strategic partner: The role of human resources in gaining competitive advantage. Human Resource Management (1986-1998), 37(1), 31. 
Baron, R. A., Hmieleski, K. M., \& Henry, R. A. (2012). Entrepreneurs' dispositional positive affect: The potential benefits-and potential costs-of being "up". Journal of Business Venturing, 27(3), 310-324.

Baškarada, S., Watson, J., \& Cromarty, J. (2016). Leadership and organizational ambidexterity. Journal of Management Development, 35(6), 778-788.

Basu, R., \& Green, S. G. (1997). Leader-member exchange and transformational leadership: An empirical examination of innovative behaviors in leader-member dyads. Journal of Applied Social Psychology, 27(6), 477-499.

Berkhout, A.J. \& Van Der Duin, P.A. (2007). New ways of innovation: an application of the cyclic innovation model to the mobile telecom industry. International journal of technology management, 40(4), 294-309.

Bessant, J., Lamming, R., Noke, H. \& Phillips, W. (2005), “Managing innovation beyond the steady state", Technovation, Vol. 25, 1366-76.

Birkinshaw, J., \& Gupta, K. (2013). Clarifying the distinctive contribution of ambidexterity to the field of organization studies. Academy of Management Perspectives, 27(4), 287-298.

Birkinshaw, J., Hamel, G., \& Mol, M. J. (2008). Management innovation. Academy of management Review, 33(4), 825-845.

Bledow, R., Frese, M., Anderson, N. R., Erez, M., \& Farr, J. L. (2009). A dialectic perspective on innovation: Conflicting demands, multiple pathways, and ambidexterity. Industrial and Organizational Psychology: Perspectives on Science and Practice, 2(3), 305-337.

Bledow, R., Frese, M., \& Müller, V. (2011). Ambidextrous leadership for innovation: The influence of culture. In W. H. Mobley M. Li \& Y. Wang (Eds.), Advances in global leadership, Vol. 6 (pp. 41-69) Bingley, UK: Emerald Group Publishing

Bodlaj, M., Kadic-Maglajlic, S. \& Vida, I. (2018). Disentangling the impact of different innovation types, financial constraints and geographic diversification on SMEs' export growth. Journal of Business Research, in press, Corrected proof. https://doi.org/10.1016/j.jbusres.2018.10.043

Bommer, M., \& Jalajas, D. (2002). The innovation work environment of high-tech SMEs in the USA and Canada. RED Management, 32(5), 379-386.

Cavazotte, F., Moreno, V., \& Hickmann, M. (2012). Effects of leader intelligence, personality and emotional intelligence on transformational leadership and managerial performance. The Leadership Quarterly, 23, 443-455.

Cao, Q., Gedajlovic, E., \& Zhang, H. (2009). Unpacking organizational ambidexterity: Dimensions, contingencies, and synergistic effects. Organization Science, 20(4), 781796.

Cerny, C.A., \& Kaiser, H.F. (1977). A study of a measure of sampling adequacy for factor-analytic correlation matrices. Multivariate Behavioral Research, 12(1), 43-47. 
Chang, Y. Y., \& Hughes, M. (2012). Drivers of innovation ambidexterity in small-to medium-sized firms. European Management Journal, 30(1), 1-17.

Charbonnier-Voirin, A., \& Roussel, P. (2012). Adaptive performance: A new scale to measure individual performance in organizations. Canadian Journal of Administrative Sciences/Revue Canadienne des Sciences de l'Administration, 29(3), 280-293.

Chen, T., Li, F., \& Leung, K. (2016). When does supervisor support encourage innovative behavior? Opposite moderating effects of general self-efficacy and internal locus of control. Personnel Psychology, 69, 123-158.

Chen, Y., Tang, G., Jin, J., Xie, Q., \& Li, J. (2014). CEOs' transformational leadership and product innovation performance: The roles of corporate entrepreneurship and technology orientation. Journal of Product Innovation Management, 4(31), 2-17.

CIPD Annual Learning and Talent Development Survey Report 2012.

Crane, A., Matten, D., \& Moon, J. (2004). Stakeholders as citizens? Rethinking rights, participation, and democracy. Journal of Business Ethics, 53(1-2), 107-122.

Cronbach, L. J. (1951). Coefficient alpha and the internal structure of tests. psychometrika, 16(3), 297-334.

Dahlander, L., \& Gann, D. M. (2010). How open is innovation?. Research policy, 39(6), 699-709.

Damanpour, F. (1996). “Organizational complexity and innovation", Management Science, Vol. 42 No. 5, 693-716.

De Jong, J. (2006). Individual innovation: the connection between leadership and employees' innovative work behavior. EIM Business and Policy Research. (No. R200604).

Denison, D. R., Hooijberg, R., \& Quinn, R. E. (1995). Paradox and performance: Toward a theory of behavioral complexity in managerial leadership. Organization Science, 6(5), 524-540.

Drucker, P. (2014). Innovation and entrepreneurship. Routledge.

Duncan, R. B. (1976). The ambidextrous organization: Designing dual structures for innovation. The management of organization, 1(1), 167-188.

Dunne, T. C., Aaron, J. R., McDowell, W. C., Urban, D. J., \& Geho, P. R. (2016). The impact of leadership on small business innovativeness. Journal of Business Research, 69(11), 4876-4881.

Ebben, J. J., \& Johnson, A. C. (2005). Efficiency, flexibility, or both? Evidence linking strategy to performance in small firms. Strategic Management Journal, 26(13), 12491259.

Edmondson, A. (1999). Psychological safety and learning behavior in work teams. Administrative science quarterly, 44(2), 350-383.

Edwards, T., Delbridge, R. \& Munday, M. (2005). “Understanding innovation in small and medium-sized enterprises: a process manifest", Technovation, Vol. 25, 1119-27. 
Efron, B. (1979). Computers and the theory of statistics: thinking the unthinkable. SIAM review, 21(4), 460-480.

Farjoun, M. (2010). Beyond dualism: Stability and change as a duality. Academy of Management Review, 35(2), 202-225.

Federation of Small Business Statistics (2016). Available online on http://www.fsb.org.uk/media-centre/small-business-statistics. Accessed on October 10, 2017.

Florida, R., \& Goodnight, J. (2005). Managing for creativity. Harvard business review, 83(7), 124.

Fornell, C. \& Larcker, D. F. (1981). Structural equation models with unobservable variables and measurement error: Algebra and statistics. Journal of Marketing Research, 18(3), 382-388.

Gibson, C.B. \& Birkinshaw, J. (2004), “The antecedents, consequences, and mediating role of organizational ambidexterity", Academy of Management Journal, Vol. 47 No. 2, 209-226.

Gong, Y., Huang, J.-C., \& Farh, J.-L. (2009). Employee learning orientation, transformational leadership, and employee creativity: The mediating role of employee creative self-efficacy. Academy of Management Journal, 52, 765-778.

Greenwood, M., \& Anderson, E. (2009). 'I used to be an employee but now I am a stakeholder': implications of labelling employees as stakeholders. Asia Pacific Journal of Human Resources, 47(2), 186-200.

Grinstein, A., \& Goldman, A. (2006). Characterizing the technology firm: An exploratory study. Research Policy, 35(1), 121-143.

Gupta, A. K., Smith, K. G., \& Shalley, C. E. (2006). The interplay between exploration and exploitation. Academy of Management Journal, 49(4), 693-706.

Gumusluoglu, L., \& Ilsev, A. (2009). Transformational leadership, creativity, and organizational innovation. Journal of business research, 62(4), 461-473.

Hair Jr, J. F., Anderson, R. E., Tatham, R. L., \& Black, W. C. (1995). Multiple discriminant analysis. Multivariate data analysis, 178-256.

Hayes, A. F. (2013). PROCESS: A versatile computational tool for observed variable mediation, moderation, and conditional process modeling [White paper].

He, Z.L. \& Wong, P.K (2004). Exploration vs. exploitation: An empirical test of the ambidexterity hypothesis. Organization science, 15(4), 481-494.

Hoegl, M., \& Parboteeah, K. P. (2006). Team reflexivity in innovative projects. RED Management, 36(2), 113-125.

Hotho, S., \& Champion, K. (2011). Small businesses in the new creative industries: innovation as a people management challenge. Management Decision, 49(1), 29-54. 
Hooijberg, R. (1996). A multidirectional approach toward leadership: An extension of the concept of behavioral complexity. Human Relations, 49(7), 917-946.

Hooker, H., \& Achur, J. (2014). First findings from the UK Innovation survey 2013. Department for business innovation and skills (BIS), London.

Hunter, S.T., Thoroughgood, C.N., Myer, A.T. \& Ligon, G.S. (2011). Paradoxes of leading innovative endeavors: Summary, solutions, and future directions. Psychology of Aesthetics, creativity, and the arts, 5(1), 54.

Iles, P., \& Preece, D. (2006). Developing leaders or developing leadership? The Academy of Chief Executives' programmes in the North East of England. Leadership, 2(3), 317-340.

Jansen, J., Vera, D. \& Crossan, M. (2009). Strategic leadership for exploration and exploitation: The moderating role of environmental dynamism. The Leadership Quarterly, 20(1), 5-18.

Jaussi, K. S., \& Dionne, S. D. (2003). Leading for creativity: The role of unconventional leader behavior. The Leadership Quarterly, 14(4-5), 475-498.

Junni, P., Sarala, R. M., Taras, V., \& Tarba, S. Y. (2013). Organizational ambidexterity and performance: A meta-analysis. The Academy of Management Perspectives, 27(4), 299312.

Kaiser, H. F. (1974). An index of factorial simplicity. Psychometrika, 39, 31-36.

Kaiser, R. B., \& Overfield, D. V. (2010). Assessing flexible leadership as a mastery of opposites. Consulting Psychology Journal: Practice and Research, 62, 105-118.

Kang, J.H., Solomon, G.T. \& Choi, D.Y. (2015). CEOs' leadership styles and managers' innovative behavior: Investigation of intervening effects in an entrepreneurial context. Journal of Management Studies, 52(4), 531-554.

Kaufmann, A. \& Tödtling, F. (2002). How effective is innovation support for SMEs? An analysis of the region of Upper Austria. Technovation, 22(3), 147-159.

Koryak, O., Lockett, A., Hayton, J., Nicolaou, N., \& Mole, K. (2018). Disentangling the antecedents of ambidexterity: Exploration and exploitation. Research Policy, 47(2), 413427.

Kutner, M. H., Neter, J., Nachtsheim, C. J., \& Li, W. (2004). Applied statistical linear models.

Larsson, J., \& Vinberg, S. (2010). Leadership behavior in successful organizations: Universal or situation-dependent?. Total quality management, 21(3), 317-334.

Lee, K., Woo, H. G., \& Joshi, K. (2017). Pro-innovation culture, ambidexterity and new product development performance: Polynomial regression and response surface analysis. European Management Journal, 35(2), 249-260. 
Leonidou, E., Christofi, M., Vrontis, D., \& Thrassou, A. (2018). An integrative framework of stakeholder engagement for innovation management and entrepreneurship development. Journal of Business Research.

Levinthal, D.A. \& March, J.G. (1993). The myopia of learning. Strategic management journal, 14(S2), 95-112.

Lewis, M.W., Andriopoulos, C., \& Smith, W (2014). 'Paradoxical leadership to enable strategic agility', California Management Review, 56(3), p.58-77.

Lin, H.-E., \& McDonough III, E. F. (2011). Investigating the Role of Leadership and Organizational Culture in Fostering Innovation Ambidexterity. IEEE Transactions on Engineering Management, 58(3), 497-509.

Lin, H.-E., McDonough, E. F., Lin, S.-J. \& Lin, C. Y.-Y. (2013), Managing the Exploitation/Exploration Paradox: The Role of a Learning Capability and Innovation Ambidexterity. J Prod Innov Manag, 30, 262-278.

Lubatkin, M.H, Simsek, Z., Ling, Y., \& Veiga, J. F. (2006). Ambidexterity and Performance in Small-to Medium-Sized Firms: The Pivotal Role of Top Management Team Behavioral Integration Journal of Management, Vol. 32 No. 5.

March, J.G. (1991). Exploration and exploitation in organizational learning, Organization Science, Vol. 2 No. 1, 71-87.

Matzler, K., Schwarz, E., Deutinger, N., \& Harms, R. (2008). The relationship between transformational leadership, product innovation and performancein SMEs. Journal of Small Business E Entrepreneurship, 21(2), 139-151.

Mintzberg, H. (1979). The structuring of organizations. Englewood-Cliffs, NJ: Prentice-Hall.

Mom, T.J., Van Den Bosch, F.A. \& Volberda, H.W. (2009). Understanding variation in managers' ambidexterity: Investigating direct and interaction effects of formal structural and personal coordination mechanisms. Organization Science, 20(4), 812-828.

Mumford, M. D., \& Licuanan, B. (2004). Leading for innovation: Conclusions, issues, and directions. The Leadership Quarterly, 15(1), 163-171

Nunally, J. C. (1978). Psychometric theory 2nd ed. NY: McGraw-Hill.

OECD and Eurostat. (2005). Oslo Manual: Guidelines for collecting and interpreting technological innovation data. Report for the OECD.

Oldham, G.R. \& Cummings, A. (1996), “Employee creativity: personal and contextual factors at work", Academy of Management Journal, Vol. 39 No. 3, pp. 607-34.

O'Reilly, C.A. \& Tushman, M.L. (2008). Ambidexterity as a dynamic capability: Resolving the innovator's dilemma. Research in organizational behavior, 28, 185-206.

Paradkar, A., Knight, J., \& Hansen, P. (2015). Innovation in start-ups: Ideas filling the void or ideas devoid of resources and capabilities?. Technovation, 41, 1-10. 
Podsakoff, P. M., MacKenzie, S. B., Lee, J.-Y., \& Podsakoff, N. P. (2003). Common method biases in behavioral research: A critical review of the literature and recommended remedies. Journal of Applied Psychology, 88(5), 879-903.

Pulakos, E. D., Arad, S., Donovan, M. A., \& Plamondon, K. E. (2000). Adaptability in the work place: Development of taxonomy of adaptive performance. Journal of Applied Psychology, 85(4), 612-624.

Reuvers, M., van Engen, M. L., Vinkenburg, C. J., \& Wilson-Evered, E. (2008). Transformational leadership and innovative work behavior: Exploring the relevance of gender differences. Creativity and Innovation Management, 17(3), 227-244.

Rosing, K., Frese, M., \& Bausch, A. (2011). Explaining the heterogeneity of the leadership-innovation relationship: Ambidextrous leadership. The leadership quarterly, 22(5), 956-974.

Rosing, K., Rosenbusch, N., \& Frese, M. (2010). Ambidextrous leadership in the innovation process. In Innovation and international corporate growth (pp. 191-204). Springer, Berlin, Heidelberg.

Rosing, K., \& Zacher, H. (2016). A New Perspective on Individual Ambidexterity and its Relationship with Innovative Performance. In Academy of Management Proceedings (Vol. 2016 (1), p. 14293). Academy of Management.

Ryan, J. C., \& Tipu, S. A. (2013). Leadership effects on innovation propensity: A twofactor full range leadership model. Journal of Business Research, 66(10), 2116-2129.

Schumpeter, Joseph A. (1965). The Theory of Economic Development: An Enquiry into Profits, Credit, interest and the Business Cycle (Oxford: Oxford University Press, fourth printing, [originally published 1934].

Seligman, M.E. \& Csikszentmihalyi, M., 2000. Positive psychology: An introduction (Vol. 55, No. 1, p. 5). American Psychological Association.

Shalley, C. E., Gilson, L. L., \& Blum, T. C. (2009). Interactive effects of growth need strength, work context, and job complexity on self-reported creative performance. Academy of Management Journal, 52(3), 489-505.

Shalley, C. E., Zhou, J., \& Oldham, G. R. (2004). The effects of personal and contextual characteristics on creativity: Where should we go from here?. Journal of management, 30(6), 933-958.

Shrader, C.B., Mulford, C.L. \& Blackburn, V.L., (1989). Strategic and operational planning, uncertainty, and performance in small firms. Journal of Small Business Management, 27(4), p.45.

Shrout, P. E., \& Bolger, N. (2002). Mediation in experimental and nonexperimental studies: new procedures and recommendations. Psychological methods, 7(4), 422.

Shibata, T., Baba, Y., Kodama, M., \& Suzuki, J. (2018). Managing ambidextrous organizations for corporate transformation: a case study of Fujifilm. RED Management. 
Smith, W.K., \& Tushman, M.L. (2005). Managing strategic contradictions: A top management model for managing innovation streams. Organization science, 16(5), 522536.

Tajvidi, M., \& Karami, A., (2015). Product Development Strategy, Innovation Capacity and Entrepreneurial Firm Performance in High-Tech SMEs. Palgrave MacMillan, UK.

Tidd, J., \& Bessant, J. (2011). Managing Innovation: Integrating Technological, Market and Organizational Change. Chichester: John Wiley \& Sons.

Tidd, J., Bessant, J., \& Pavitt, K. (2005). Managing Innovation: Integrating Technological, Market and Organizational Change (third edition). Chichester: Wiley

Tushman, M.L. \& O’Reilly, C.A. (1996). “The ambidextrous organization: managing evolutionary and revolutionary change", California Management Review, Vol. 38, 1-23.

Tung, F.C. \& Yu, T.W. (2016). Does innovation leadership enhance creativity in hightech industries? Leadership E Organization Development Journal, 37(5), 579-592.

Vaccaro, I. G., Jansen, J. J., Van Den Bosch, F. A., \& Volberda, H. W. (2012). Management innovation and leadership: The moderating role of organizational size. Journal of Management Studies, 49(1), 28-51.

Van de Vrande, V., De Jong, J. P., Vanhaverbeke, W., \& De Rochemont, M. (2009). Open innovation in SMEs: Trends, motives and management challenges. Technovation, 29(6-7), 423-437.

Vargas, M. I. R. (2015). Determinant factors for small business to achieve innovation, high performance and competitiveness: organizational learning and leadership style. Procedia-Social and Behavioral Sciences, 169, 43-52.

Venkataraman, S. (2002). Stakeholder value equilibration and the entrepreneurial process. Business Ethics Quarterly: The Ruffin Series, 3, 45-58.

Vera, D. \& Crossan, M. (2004), "Strategic leadership and organizational learning", Academy of Management Review, Vol. 29 No. 2, 222-240.

Wadhwa, A., \& Kotha, S. (2006). Knowledge creation through external venturing: Evidence from the telecommunications equipment manufacturing industry. Academy of Management Journal, 49(2006), 819-835.

Wang C. L., \& Rafiq M. (2014). Ambidextrous organizational culture, contextual ambidexterity and new product innovation: A comparative study of UK and Chinese high-tech firms. British Journal of Management, 25, 58-76.

Wang, P., \& Rode, J.C. (2010). Transformational leadership and follower creativity: The moderating effects of identification with leader and organizational climate. Human Relations, 63, 1105-1128.

Wang, P., \& Zhu, W. (2011). Mediating role of creative identity in the influence of transformational leadership on creativity: Is there a multilevel effect? Journal of Leadership and Organizational Studies, 18, 25-39. 
Wen, Z., \& Fan, X. (2015). Monotonicity of effect sizes: Questioning kappa-squared as mediation effect size measure. Psychological methods, 20(2), 193.

Farr, J. L., \& West, M. A. (Eds.). (1990). Innovation and creativity at work: Psychological and organizational strategies. Wiley.

Wu, S., Levitas, E., \& Priem, R. L. (2005). CEO tenure and company invention under differing levels of technological dynamism. Academy of Management Journal, 48(5), 859873.

Xia, T., \& Roper, S. (2016). Unpacking open innovation: absorptive capacity, exploratory and exploitative openness, and the growth of entrepreneurial biopharmaceutical firms. Journal of Small Business Management, 54(3), 931-952.

Yukl, G. A., \& Mahsud, R. (2010). Why flexible and adaptive leadership is essential. Consulting Psychology Journal: Practice and Research, 62, 81-93.

Zacher, H., Robinson, A.J. \& Rosing, K. (2014). Ambidextrous Leadership and Employees' Self-Reported Innovative Performance: The Role of Exploration and Exploitation Behaviors. The Journal of Creative Behavior.

Zacher, H. \& Rosing, K. (2015). Ambidextrous leadership and team innovate on. Leadership E Organization Development Journal, 36(1), 54-68.

Zacher, H. \& Wilden, R.G. (2014). A daily diary study on ambidextrous leadership and self-reported employee innovation. Journal of occupational and organizational psychology, 87(4), 813-820.

Zahra, S., Ireland, R., \& Hitt, M. (2000). International Expansion by New Venture Firms: International Diversity, Mode of Market Entry, Technological Learning, and Performance. The Academy of Management Journal, 43(5), 925-950. 
Table 1. Opening and Closing Leadership Behaviors

\begin{tabular}{|l|ll|}
\hline Opening leadership behaviors & Closing leadership behaviors \\
\hline $\begin{array}{l}\text { Allowing different ways of } \\
\text { accomplishing a task }\end{array}$ & $\begin{array}{l}\text { Monitoring and controlling goal } \\
\text { attainment }\end{array}$ \\
\hline $\begin{array}{l}\text { Encouraging experimentation with } \\
\text { different ideas }\end{array}$ & Establishing routines & \\
\hline Motivating to take risks & Taking corrective action \\
\hline $\begin{array}{l}\text { Giving possibilities for independent } \\
\text { thinking and acting }\end{array}$ & Controlling adherence to rules \\
\hline Giving room for own ideas & $\begin{array}{l}\text { Paying attention to uniform task } \\
\text { accomplishment }\end{array}$ \\
\hline Allowing errors & Sanctioning errors \\
\hline Encouraging error learning & Sticking to plans \\
\hline
\end{tabular}

(Source: Rosing et al., 2011; p.967) 
Figure 1. Model of Ambidextrous Leadership

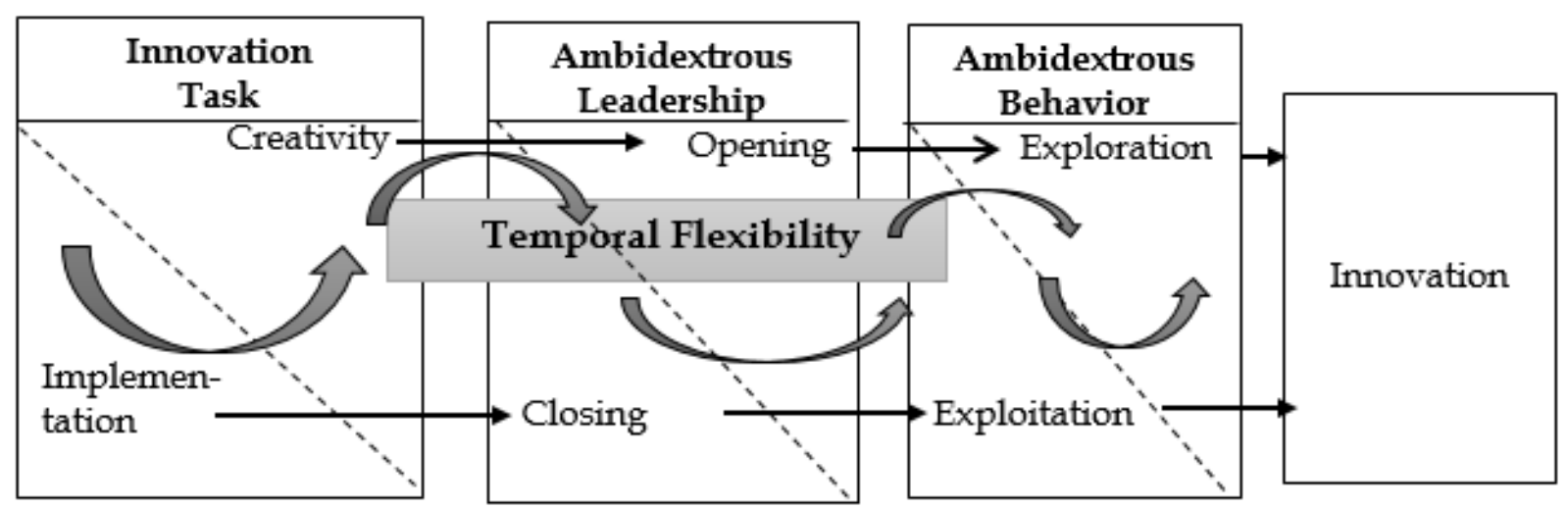

(Adapted from Rosing et al., 2011; p.966) 
Figure 2. Relationship between Ambidextrous Leadership and Employee Ambidexterity

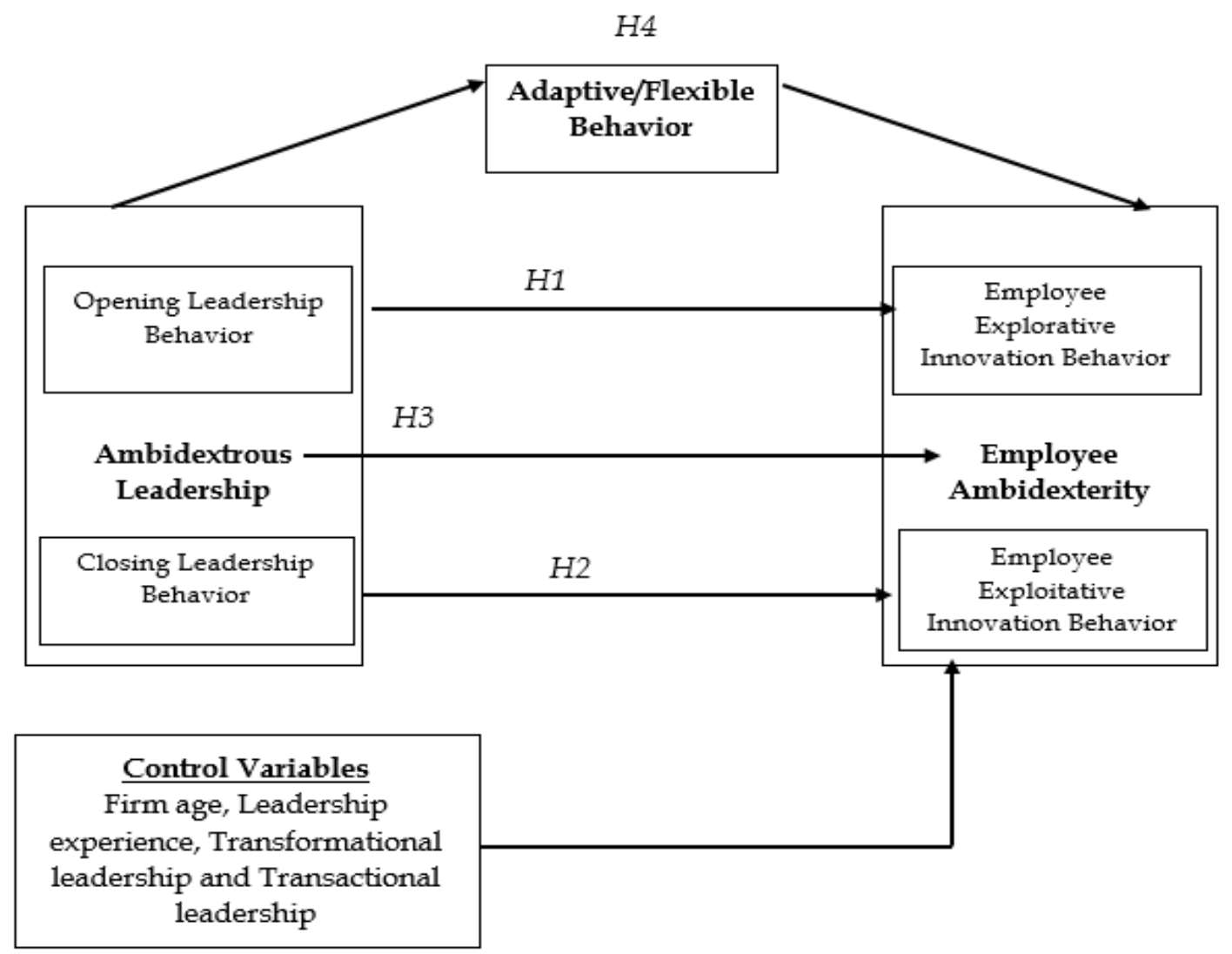


Table 2. Sample Description and Demographic Characteristics

\begin{tabular}{lcc}
\hline Demographics of the Leader & \multicolumn{2}{c}{ Frequency } \\
\cline { 2 - 3 } $\mathbf{N}$ & $\mathbf{( \% )}$ \\
Respondents Age & 2 & 2.0 \\
17-25 & 11 & 11.2 \\
$26-35$ & 22 & 22.4 \\
$36-45$ & 36 & 36.7 \\
$46-54$ & 27 & 27.6 \\
Over 55 & & \\
Years of experience in present job & 10 & 10.2 \\
Less than 1 year & 24 & 24.5 \\
1-5 years & 17 & 17.3 \\
6-10 years & 16 & 16.3 \\
11-15 years & 31 & 31.6 \\
More than 15 years & & \\
Gender & 70 & 71.4 \\
Male & 28 & 28.6 \\
Female & & \\
Highest Academic qualification & 19 & 19.4 \\
GCSE/Vocational Qualification & 51 & 52.0 \\
First level university degree & 51 \\
MBA/Masters/PhD & 28 & 28.6 \\
& \multicolumn{2}{c}{} \\
Age of the firm & Frequency \\
& $\mathbf{N}$ & $\mathbf{( \% )}$ \\
0-3 years & 13 & 13.3 \\
4-6 years & 10 & 10.2 \\
7-9 years & 8 & 8.2 \\
10 years and above & 67 & 68.4 \\
& & \\
& &
\end{tabular}


Table 3. Means (M), Standard Deviations (SD), and Correlations of Variables

\begin{tabular}{|c|c|c|c|c|c|c|c|c|c|c|c|c|c|}
\hline Variables & M & SD & 1 & 2 & 3 & 4 & 5 & 6 & 7 & 8 & 9 & 10 & 11 \\
\hline 1. Opening Leadership behaviors & 3.8216 & .57574 & - & & & & & & & & & & \\
\hline 2.Closing Leadership behaviors & 3.5609 & .50783 & .095 & - & & & & & & & & & \\
\hline 3.Transformational Leadership & 3.6154 & .49197 & $.423^{* *}$ & .166 & - & & & & & & & & \\
\hline 4.Transactional Leadership & 3.4516 & .39508 & -.027 & $.326^{* *}$ & $.361^{* *}$ & - & & & & & & & \\
\hline 5.Adaptive/Flexible behavior & 3.8908 & .33980 & $.389^{* *}$ & $.169^{*}$ & $.334^{* *}$ & .180 & - & & & & & & \\
\hline 6. Employee Exploration & 3.8923 & .55256 & $.375^{* *}$ & $.276^{* *}$ & $.467^{* *}$ & $.265^{\star *}$ & $.367^{* *}$ & - & & & & & \\
\hline 7. Employee Exploitation & 4.0459 & .51456 & .184 & $.372^{* *}$ & .195 & $.301^{* *}$ & .129 & $.259^{* *}$ & - & & & & \\
\hline 8. Leader's age & 3.7653 & 1.0434 & .141 & .168 & .084 & $.234^{*}$ & .071 & .176 & .110 & - & & & \\
\hline 9.Leadership experience & 3.9490 & 1.3032 & 0.74 & $.334^{* *}$ & .115 & .183 & -.042 & .065 & -.016 & $.504^{* *}$ & - & & \\
\hline 10. Firm Age & 3.3163 & 1.1085 & -.062 & .025 & -.101 & .151 & -.110 & -.108 & .199 & $.204^{*}$ & .002 & - & \\
\hline 11.Gender & 1.2857 & .45408 & .134 & -.071 & .066 & -.152 & $.245^{*}$ & .053 & .160 & $-.346^{* *}$ & $-.279^{* *}$ & -.125 & - \\
\hline 12.Highest Academic Qualification & 2.0918 & .68994 & -.005 & .008 & -.015 & $-.260^{* *}$ & .034 & -.031 & -.028 & -.044 & .065 & -.025 & -.021 \\
\hline
\end{tabular}


Table 4. Reliability and Validity.

\section{CONSTRUCT/INDICATORS}

Opening Leadership

Allowing different ways of accomplishing a task

Encouraging experimentation with different ideas

Motivating others to take risks

Giving possibilities for independent thinking and acting

Giving room for the ideas of others

Allowing errors

Encouraging error learning

Closing leadership

Monitoring goals and controls goal attainment

Establishing routines

Taking corrective action

Controlling adherence to rules

Sticking to plans

Paying attention to uniform task accomplishment

\section{Employee Exploration}

Searching for new possibilities with respect to their work

Evaluating diverse options with respect to their work

Focusing on strong renewal of products/services or processes

Actively engaging in activities requiring them to be adaptable

Actively engaging in activities requiring them to learn new skills or knowledge

\section{Employee Exploitation}

Actively engaging in activities in which they have accumulated a lot of experience

Actively engaging in activities in which they clearly know how to conduct

Actively engaging in activities that are primarily focused on achieving short-term goals

Actively engaging in activities in which they can properly conduct using their existing knowledge

\section{COMPOSITE FACTOR}

RELIABILITY LOADING

0.812

0.62

.671

.718

.457

.586

.659

0.751

0.58

.548

.583

.485

.616

.617

.621

0.84

0.51

.690

.652

.743

.735

.752

0.83

0.50 
Actively engaging in activities which clearly fit into existing

company policy

\section{Adaptive/Flexible behavior}

I am able to achieve total focus on the situation to act quickly

I quickly decide on the actions to take to resolve problems

I analyse possible solutions and their ramifications quickly to

select the most appropriate one

Developing good relationships with all my subordinates is an

important factor of my effectiveness

I try to understand the viewpoints of my subordinates to

improve my interaction with them

I learn new ways to do my job better in order to collaborate

with others

I willingly adapt my behavior whenever I need to in order to work well with others

I undergo training on a regular basis at work or outside of work to keep my competencies up to date

I am on the lookout for the latest innovations related to my

field of work to improve the way I work

I look for every opportunity that enables me to improve my performance (training, group projects, exchanges with colleagues or subordinates)

Because of my self-control, my subordinates ask for my advice regularly when situations are difficult

I keep my cool in situations where I am required to make many decisions

I look for solutions by having a calm discussion with my subordinates

I do not hesitate to go against established ideas and propose an innovative solution

At work, subordinates rely on me to suggest new solutions

I use a variety of sources/types of information to come up with an innovative solution 
Table 5. CFA for Goodness-of Fit Measurement

Scales

$$
\chi 2
$$

OLB * CLB

37.507

df

$\chi 2 / \mathrm{df} \quad \mathrm{GF}$

AGFI CFI

RMSEA

Exploration

20.175

33

$1.137 \quad 0.92$

0.87

0.99

0.038

*Exploitation

Adaptive/ flexible

93.353

80

$\begin{array}{lll}1.167 & 0.89 & 0.83\end{array}$

0.98

0.041

leadership

MLQ

17.835

13

$1.372 \quad 0.95$

0.90

0.98

0.048

(Transformational

and Transactional

leadership) 
Figure 3. The Effect of Ambidextrous Leadership on Employee Ambidextrous Innovation Behaviors (color print)

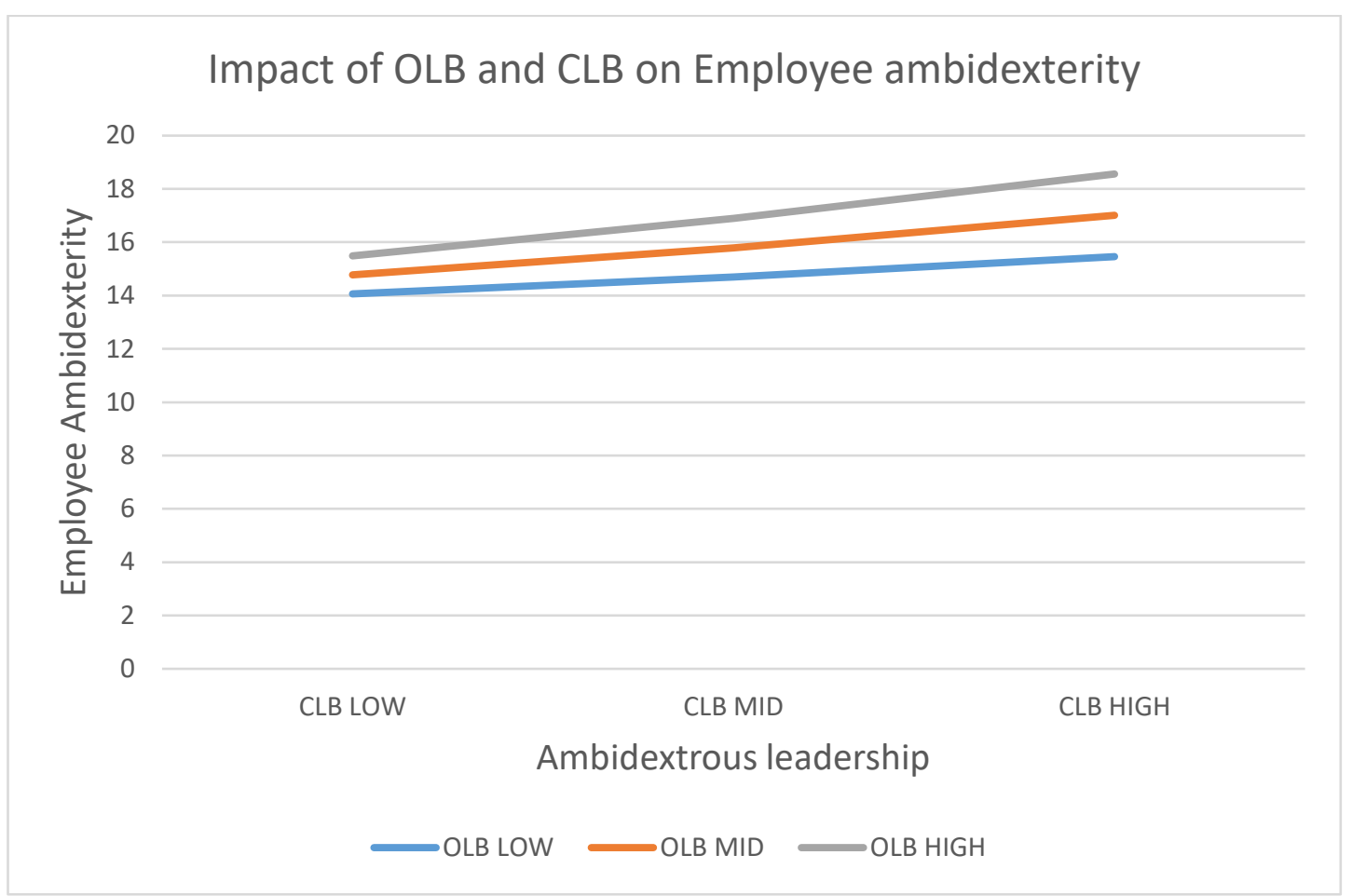


Figure 4. The mediating effect of Adaptive/flexible leadership

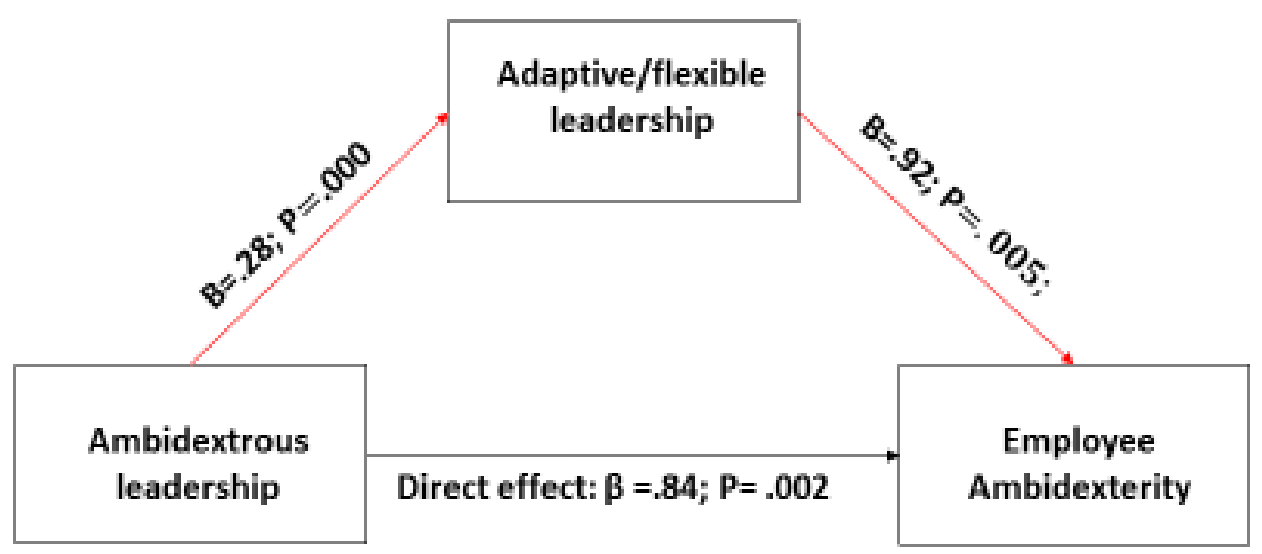

Indirect effect: $\beta=.26,95 \%, \mathrm{Cl}$

[0.0809, 0.5458] 
Table 6. VIF scores and Tolerance levels

$\begin{array}{lll}\text { Variable } & \text { Tolerance level } & \text { VIF score } \\ \text { OLB } & .384 & 2.61 \\ \text { CLB } & .250 & 3.92 \\ \text { Adaptive/Flexible } & .695 & 1.43 \\ \text { Leadership } & & \\ \text { Transformational } & .548 & 1.82 \\ \text { leadership } & & \\ \text { Transactional leadership } & .239 & 4.0\end{array}$


Table 7. Results of Regression Analyses

\begin{tabular}{|c|c|c|c|c|c|c|c|}
\hline \multirow[t]{2}{*}{ Predictor Variables } & \multicolumn{2}{|c|}{$\begin{array}{l}\text { Employee } \\
\text { Exploration }\end{array}$} & \multicolumn{2}{|c|}{$\begin{array}{l}\text { Employee } \\
\text { Exploitation }\end{array}$} & \multicolumn{3}{|c|}{ Employee Ambidexterity } \\
\hline & Step 1 & Step 2 & Step 1 & Step 2 & Step 1 & Step 2 & Step 3 \\
\hline Step 1 & -.18 & -.17 & .09 & .10 & -.05 & -.04 & -.04 \\
\hline Firm Age & $(.084)$ & $(.087)$ & $(.426)$ & $(.365)$ & $(.610)$ & $(.637)$ & $(.674)$ \\
\hline Leadership experience & $\begin{array}{l}.19 \\
(.070)\end{array}$ & $\begin{array}{l}.19^{*} \\
(.050)\end{array}$ & $\begin{array}{l}.06 \\
(.573)\end{array}$ & $\begin{array}{l}.03 \\
(.810)\end{array}$ & $\begin{array}{l}.20 \\
(.044)\end{array}$ & $\begin{array}{l}.19 \\
(.061)\end{array}$ & $\begin{array}{l}.16 \\
(.098)\end{array}$ \\
\hline Transformational leadership & $\begin{array}{l}.25^{* *} \\
(.005)\end{array}$ & $\begin{array}{l}.17 \\
(.105)\end{array}$ & $\begin{array}{l}.11 \\
(.337)\end{array}$ & $\begin{array}{l}.08 \\
(.467)\end{array}$ & $\begin{array}{l}.40^{*} \\
(.000)\end{array}$ & $\begin{array}{l}.28^{*} \\
(.013)\end{array}$ & $\begin{array}{l}.29^{*} \\
(.012)\end{array}$ \\
\hline Transactional leadership & $\begin{array}{l}.18 \\
(.095)\end{array}$ & $\begin{array}{l}.19 \\
(.060)\end{array}$ & $\begin{array}{l}.23^{*} \\
(.042)\end{array}$ & $\begin{array}{l}.17 \\
(.128)\end{array}$ & $\begin{array}{l}.17 \\
(.113)\end{array}$ & $\begin{array}{l}.07 \\
(.684)\end{array}$ & $\begin{array}{l}.06 \\
(.691)\end{array}$ \\
\hline Step 2 & & $.31^{* * *}$ & & .099 & & $.21^{*}$ & -.026 \\
\hline Opening leadership behavior & & $\begin{array}{l}(.000) \\
.10\end{array}$ & & $\begin{array}{l}(.311) \\
.28^{\star *}\end{array}$ & & $\begin{array}{l}(.034) \\
.18\end{array}$ & $\begin{array}{l}(.847) \\
.11\end{array}$ \\
\hline Closing leadership behavior & & $(.274)$ & & $(.006)$ & & $(.326)$ & $(.526)$ \\
\hline $\begin{array}{l}\text { Step } 3 \\
\text { Ambidextrous leadership } \\
\left(\mathrm{OLB}^{*} \mathrm{CLB}\right)\end{array}$ & & & & & & & $\begin{array}{l}.32^{*} \\
(.016)\end{array}$ \\
\hline$\Delta \mathrm{R}^{2}$ & .17 & .25 & .07 & .14 & .28 & .30 & .34 \\
\hline $\mathrm{R}^{2}$ & .21 & .30 & .12 & .20 & .31 & .34 & .39 \\
\hline $\mathrm{F}$ & $5.97^{* * *}$ & $6.5^{* * *}$ & $3.1^{* *}$ & $4.22^{* *}$ & $10.22^{* * *}$ & $7.94^{* * *}$ & $8.04^{* * *}$ \\
\hline Sig. (P-value) & $(.000)$ & $(.000)$ & $(.002)$ & $(.002)$ & $(.000)$ & $(.000)$ & $(.000)$ \\
\hline $\mathrm{N}$ & 98 & 98 & 98 & 98 & 98 & 98 & 98 \\
\hline
\end{tabular}


